\title{
Artigo \\ Cinco Vidas: travestilidades, \\ gênero, sexualidades e etnicidades \\ no interior da Paraíba
}

\author{
Martinho Tota ${ }^{1}$ \\ Universidade do Estado do Rio de Janeiro
}

RESUMO: Os principais estudos socioantropológicos produzidos no (ou sobre o) contexto brasileiro acerca de lésbicas, gays, travestis e transexuais tiveram como locus paisagens urbanas, metropolitanas, de modo que pouco sabemos sobre como pessoas vivenciam sexualidades e identidades de gênero que divergem da "matriz heterossexual" em espaços outros, como o mundo rural, as pequenas cidades do interior brasileiro ou territórios indígenas. Além disso, no caso específico dos trabalhos realizados sobre a temática travesti, observamos a recorrência da associação entre travestilidade e prostituição. Assim, este artigo objetiva - a partir das histórias de vida de cinco travestis indígenas, habitantes de cidades do interior do estado da Paraíba - fornecer uma contribuição no sentido de agregar outros elementos para os(as) estudiosos(as) da questão travesti, bem como matizar o problema da prostituição através de seus discursos e de suas peculiaridades biográficas.

PALAVRAS-CHAVE: Travestilidade, sexualidade, gênero, etnicidade, histórias de vida. 


\section{Introdução}

O presente artigo é fruto de trabalho de campo desenvolvido entre os anos de 2009 e 2010 na Microrregião do Litoral Norte do estado da Paraíba ${ }^{2}$. O escopo do estudo, que resultou em minha tese de doutorado (cf. Tota, 2012), era o de analisar processos e fluxos identitários complexos envolvendo etnicidade, gênero, geração e sexualidades nessa região do país, onde encontramos a Terra Indígena Potiguara, trazendo à tona, portanto, aspectos da vida social pouco trabalhados pelos pesquisadores dos "índios do Nordeste", em cujos estudos o fenômeno étnico aparece frequentemente como uma instância englobante (cf. Sidnei Peres, 1992; Grünewald, 1993; Valle, 1993; Arruti, 1996, 2004, entre outros). Paralelamente, inserindo-me na agenda dos debates sobre gênero e sexualidades, nesta pesquisa procurei mostrar o quanto estes vetores identitários (o étnico, o sexual e o gênero) se interseccionam ${ }^{3}$ (ou se dissociam) situacionalmente com categorias políticas, familiares, religiosas, morais, entre outras.

Antes de prosseguir, faz-se necessário apresentar em linhas gerais o contexto no qual a pesquisa foi empreendida. O trabalho de campo concentrou-se nos municípios da Baía da Traição e Marcação. O primeiro fica a 92 quilômetros de João Pessoa, capital do estado da Paraíba, e conta com uma população estimada em 8.012 habitantes, dos quais 5.687 são classificados como “índios" (estas informações foram obtidas em consulta realizada no sítio eletrônico do Instituto Brasileiro de Geografia e Estatística - IBGE, e referem-se ao censo demográfico do ano de 2010). Já o município de Marcação fica a 66 quilômetros de João Pessoa e sua população é de 7.609 habitantes, dos quais 5.895 são classificados como indígenas (IBGE, 2010).

As Terras Indígenas Potiguara compreendem boa parte do território desses dois municípios. Baía da Traição, por exemplo, é cercado por 12 aldeias ou povoados ${ }^{4}$, que constituem a Terra Indígena Potiguara, cuja extensão é de 21.238 hectares. Já no município de Marcação encontra-se a Terra Indígena Jacaré de São Domingos, dividida em 14 aldeias ou povoados ${ }^{5}$, que, juntos, ocupam uma área de 5.032 hectares. Importante destacar que há ainda a Terra Indígena Potiguara de Monte-Mór (formada por quatro aldeias ${ }^{6}$ ), que ocupa uma área de 7.487 hectares. Esta última fica em Rio Tinto, segunda maior cidade do Litoral Norte paraibano, que dista 52 quilômetros de João Pessoa e cuja população é de 22.976 habitantes, dos quais 2.378 são classificados como indígenas (IBGE, 2010). Somadas, as três Terras Indígenas ocupam uma área de 33.757 hectares. 
Com uma população total estimada em 13.960 habitantes (IBGE, 2010), os Potiguara formam o único grupo indígena reconhecido do estado da Paraíba e, em termos populacionais, o maior do chamado "Nordeste etnográfico"7 . Falam apenas o português, a exemplo de quase todos os grupos indígenas do Nordeste brasileiro, com exceção dos índios Fulni-ô, falantes do Yathé.

O estudo empreendido foi iniciado junto a mulheres membros e/ou líderes de algumas associações comunitárias Potiguara. Num segundo momento, o foco da pesquisa foi a Organização dos Jovens Indígenas Potiguara (OJIP). A partir de alguns de seus integrantes, fui gradativamente adentrando uma rede formada por sujeitos autodenominados homossexuais, gays e/ou travestis. Construída a partir da investigação etnográfica e da análise teórica acerca de questões relacionadas a gênero, geração e sexualidades e a articulação destes marcadores com as etnicidades, a pesquisa respaldou-se igualmente nas histórias de vida de meus/minhas interlocutores/as.

Para o presente artigo, recortei as histórias e os enunciados de Britney, Jennifer, Scarlett, Lindsay e Naomi, cinco jovens travestis (com idades variando entre 21 e 26 anos), todas filhas de agricultores e frutos de conjugalidades interétnicas (isto é, envolvendo uma mulher "branca" e um homem "índio", ou vice-versa) ${ }^{8}$. Britney residia no núcleo urbano da Baía da Traição, enquanto Jennifer morava numa pequena aldeia afastada, porém inserida na região do referido município. Já Scarlett e Lindsay viviam na aldeia Camurupim, inserida na região do município de Marcação, porém afastada do núcleo urbano desta cidade. Quanto a Naomi, esta morava em Salema, distrito rural do município de Rio Tinto.

Considerando que a pesquisa inicialmente não teve como foco exclusivo a temática travesti, é preciso admitir o teor ensaístico (portanto nada exaustivo) apresentado neste artigo. Não obstante, o encontro com minhas cinco companheiras de pesquisa levaram-me a refletir sobre o fato de muitos dos estudos socioantropológicos produzidos no Brasil, seja no contexto indígena, seja no rural, não abordarem identidades de gênero, práticas sexuais e modelos de conjugalidades destoantes da "matriz heterossexual"" (cf., por exemplo, Heredia, 1979, 1989; Garcia Jr., 1983, 1989) ${ }^{10}$. Além disso, a partir da leitura de alguns trabalhos enfocando a temática travesti no Brasil (cf. Neusa Oliveira, 1994; Pelúcio, 2005, 2007, 2009; Benedetti, 2005; William Peres, 2005; Kulick, 2008; Patrício, 2008; Teixeira, 2008), observamos, além da ubiquidade do contexto urbano - para não dizer metropolitano - a recorrência de outro marcador frequentemente associado nestes trabalhos à travestilidade ${ }^{11}$ : a prostituição. 
O objetivo deste artigo, contudo, mais que questionar a associação entre travestilidade, urbanidade e prostituição, consiste em matizá-la a partir das trajetórias biográficas de minhas cinco interlocutoras. Trazer estas vidas à tona permite-nos contemplar contextos sociais pouco notados pelos(as) pesquisadores(as) dedicados(as) ao estudo das sexualidades e identidades de gênero que divergem da heteronormatividade ${ }^{12}$ isto é, espaços nos quais estão ausentes ou atenuados aspectos comumente apresentados como característicos das sociedades modernas contemporâneas, como o valor conferido ao individualismo, ao anonimato, à preeminência de uma "ética hedonista" (Duarte, 2004: 3233), ao afrouxamento dos vínculos familiares, etc. Ou seja, auxilia-nos tanto no mapeamento de outros cenários sociossexuais que não aqueles metropolitanos, bem como a apreender como se dão certas vivências travestis em regiões como o interior do Nordeste brasileiro. Ademais, por estarem inseridas no contexto das Terras Indígenas Potiguara, veremos em que medida o elemento étnico emerge como um aspecto adicional nas configurações social e biográfica das cinco protagonistas deste artigo.

\section{Britney}

Britney tinha 24 anos de idade quando a conheci. Era filha de agricultores e nascera na Baía da Traição. Morava nesse município com a mãe e um irmão mais velho que ela. Seu pai, um "branco"13, natural do estado do Ceará, era falecido. A mãe, filha de índios, nascera na cidade de Cabedelo, zona portuária do estado da Paraíba. Por ser ela fruto de uma união entre uma indígena e um não índio, a identidade étnica de Britney encontrava amplo espaço para "manipulação", como diria Cardoso de Oliveira (2006: 75). Sobre isso, suas palavras eram de que "eu, conforme os outros, me considero índio".

Desde "pequeno", quando via um "menino" passar, Britney sentia uma "sensação diferente, já me dava aquele fogo". Aos 8 anos ela começou a "ficar com homem, fui ficando, daí eu fui gostando e pronto. Até hoje”. Nessa época ela já usava roupas e acessórios femininos. Para Britney, a homossexualidade era "uma coisa normal. Não é porque ninguém quer ser homossexual. Eu acho que a pessoa já nasce com aquele dom. Se vai dar pra gay, é. Não tem como mudar”.

Britney me disse que "a maioria diz que só tenho eu de travesti aqui na Baía da Traição". Em outro momento, ela se definiu como "homossexual". Prestando atenção em seu depoimento, notei que em diversas passagens ela empregou palavras com terminações masculinas: “índio", “acostumado", “pequeno”, “depravado”, mesmo quando eu a tratava 
como “ela". Kulick (2008), por exemplo, observou nos discursos de suas entrevistadas o mesmo tipo de ambiguidade, interpretado por ele como decorrente de duas fases distintas vividas pelas travestis ouvidas: uma anterior ao processo de construção da travestilidade, na qual as informantes do autor se colocavam como sujeitos masculinos; e outra, referente ao presente etnográfico, na qual elas se posicionavam como indivíduos femininos. O mesmo, contudo, não poderia ser dito quanto a Britney, que, dentro de uma mesma formulação discursiva, se punha ora como sujeito masculino ("homossexual"), ora feminino ("mulher"). Atentando para este fato, insisti para que ela elaborasse sua identidade de gênero: "Eu me vejo dos dois modos. Mas mais mulher que gosta de homem do que homossexual".

A questão por mim levantada poderia ser tomada como um esforço impertinente no sentido de enclausurar minha interlocutora em uma categoria sexual ou de gênero fixa. Entretanto, minha intenção era a de entender a maneira pela qual ela interpretava sua identidade sociossexual. Eribon argumenta que:

[...] uma boa parte da cultura gay contemporânea deve sua fisionomia a essa atração pelas imagens mais caricaturais da "feminidade", a qual exprime a criatividade de uma cultura minoritária e a maneira como essa cultura é, por meio dessa forma de ironia, a melhor crítica de si mesma e das outras (2008: 113-114).

Todavia - embora não tomasse hormônios nem tivesse silicone aplicado em seu corpo como as interlocutoras de Benedetti (2005), Pelúcio (2007), Silva (2007), Kulick (2008), Patrício (2008), Duque (2009) -, Britney não mantinha o cabelo longo, usava shorts e vestidos curtos, blusas justas e decotadas, maquiagem e brincos apenas com o intuito de parecer uma "caricatura de mulher". Ao moldar seu corpo - essa "materialização contínua e incessante de possibilidades" (Bento, 2006: 86-88); esse “suporte de significados”, essa “linguagem” (Benedetti, 2005: 54-55) -, Britney se construía enquanto sujeito ${ }^{14}$.

Tratando de pessoas transexuais, Bento (2006: 25) alerta para "a necessidade de interpretar a identidade de gênero, a sexualidade, a subjetividade e o corpo como modalidades relativamente independentes no processo de construção das identidades". No caso de Britney, porém, sua identidade parecia estar respaldada simultaneamente no corpo biológico, na reelaboração deste, na atração erótica por homens e na interação sexual com os mesmos. Com isso, ela se tornava "mais mulher de que homossexual". Ao definirse assim, ao querer ser vista como tal, Britney evidencia a "plasticidade do gênero" 
(Siqueira, 2006: 15), bem como o fato de que não há uma "identidade homossexual", "transexual", "travesti", de "homem" ou "mulher", mas sim "posições de identidade, pontos de apego temporários que, simultaneamente, fixam e deslocam os sujeitos [que interpretam] performaticamente as normas de gênero" (Bento, 2006: 25, 33-34, 201).

McClintock (2010), discorrendo sobre a obra de Marjorie Garber (1991), afirma que esta última

nos estimula a ver os (sic) travestis em seus próprios termos, não como um sexo ou como um gênero, mas como apresentação da própria ambiguidade; nem como "sexo mesclado", mas sim como a corporificação e representação da contradição social. O (sic) travesti habita o limiar da distinção em categorias, desafiando "noções fáceis de binarismo e pondo em questão as categorias de "fêmea" e "macho". Garber se posiciona, assim, contra a teoria do travestismo como um progresso narrativo, que tentaria descobrir uma identidade desejada "real", seja "masculina"” ou "feminina", por trás da máscara do (sic) travesti. Para ela, ao contrário, o (sic) travesti não é equivalente a um ou outro sexo mas é, antes, a figura que habita as fronteiras nas quais as oposições são perpetuamente descompostas, desorganizadas e subvertidas" (McClintock, 2010, p. 261).

Benedetti (2005: 118) parece corroborar essa perspectiva analítica, afirmando que, no caso das travestis, "[o]s limites e fronteiras entre a sexualidade e o gênero aparecem muito borrados, confusos e fracamente delimitados (...), o que remete ao fato de que tais categorias são antes conceitos analíticos do que realidades empíricas independentes". Talvez esta seja uma chave interpretativa para entender porque Britney transitava entre "ser homossexual" e "ser mulher" sem demonstrar grande ansiedade para definir-se em termos absolutamente fixos. Entretanto, talvez a "oscilação" de Britney entre sua sexualidade e sua identidade de gênero possa ser esclarecida ao pensarmos que, quando a conheci, em 2009, Britney ainda era chamada pelos amigos mais próximos pelo seu nome masculino. Ou seja, Britney estava vivendo um momento de transição e de ressignificação de sua identidade de gênero. Acredito poder afirmar isso com algum grau de segurança por manter contato com ela mesmo depois do término do trabalho de campo. Hoje, passados mais cinco anos desde que a conheci, a persona feminina de Britney parece ter sobrepujado o "menino" que ela foi (ou acreditou ser) um dia.

Britney estudou até o sexto ano do Ensino Fundamental, mas teve de abandonar a escola para trabalhar como "babá" em João Pessoa durante dois anos. Porém, ela decidiu largar o emprego e voltar para a Baía porque “tem aquela coisa: 'viado é ladrão'. Por mais amigo que seja, mas, foi viado, é ladrão. Então, foi o caso”. Depois disso, ela trabalhou 
num bar localizado na Baía da Traição ou tomando "conta de várias mulheres grávidas". Segundo ela, a dificuldade para conseguir emprego devia-se ao fato de que, "na hora que dizem que é homossexual, que se veste desse jeito, elas já dizem logo: 'Eu não quero, por causa do meu marido'. Porque pensam que a gente vai trabalhar atrás dos maridos delas. Então, eu acho que é muito mais difícil arrumar trabalho por conta disso: preconceito”.

Britney dizia ser alvo de preconceito também por parte de homossexuais. Segundo ela, muitos evitavam serem vistos na companhia dela: "Se eles estão num canto com os amigos deles, se eu chegar, eles fazem que nem me conhecem". Para ela, a atitude desses indivíduos justificava-se ora por "ciúmes" - já que ela acreditava levar vantagem na conquista de parceiros sexuais -, ora pelo receio de se tornarem alvo de comentários maldosos por estarem na companhia de uma travesti.

Entretanto, apesar de enfatizar o problema relacionado ao preconceito, Britney procurava elaborar positivamente a percepção quanto às suas sexualidade e identidade de gênero: "Eu gosto da minha vida, tenho minha vida liberta. Eu adoro a vida que eu tenho. E foi uma vida escolhida e que eu gostei”.

\section{Jennifer}

Britney tinha uma amiga travesti que morava em Tracoeira, uma aldeia povoada por cerca de 167 pessoas e que ficava afastada do núcleo urbano da Baía da Traição. Britney a visitava com alguma frequência e, sempre que podia, presenteava-lhe com roupas. Além de Britney, outras pessoas falaram-me sobre ela, dizendo-me que Jennifer cuidava dos afazeres domésticos como se fosse "uma mulher". Em 2010, um ano, portanto, depois de ter iniciado o trabalho de campo, conheci Jennifer, graças a Britney, que estudava na mesma escola que ela. No colégio, encontrei Jennifer inteiramente trajada com roupas femininas em vários tons de rosa, inclusive a maquiagem e os acessórios que usava (brincos, pulseiras, colares). Tinha os cabelos crespos, unidos por presilhas também cor de rosa. Como havia muito barulho na escola, decidimos conversar na pousada onde eu estava hospedado, e assim fizemos. No curto trajeto até o lado de fora do colégio, fomos alvejados por uma infinidade de gracejos emitidos pelos alunos (alguns a chamaram de "gostosa").

Jennifer estava com 26 anos quando a conheci. Morava com o pai e um irmão pequeno. Sua mãe, uma não indígena, havia morrido um ano antes. Apenas o pai de Jennifer, natural de um lugarejo próximo ao município paraibano de Mataraca, era "índio". Porque sua avó paterna era "verdadeira cabocla legítima", Jennifer se considerava indígena. 
Ela era a mais velha dos quatro filhos de um casal de agricultores. Dois de seus irmãos já eram casados. Quanto ao irmão menor, "eu tô criando, tomo conta dele. Tomo conta dele e de pai. Em casa eu faço as coisas, faço almoço, vou apanhar feijão no roçado, vou plantar mandioca. A gente faz farinha, faz beiju. E assim tá vivendo”. A vida difícil fazia com que ela acalentasse o sonho de viver em outro lugar, "aqui na Baía, ou senão Mataraca, Mamanguape, esses lugares assim”. Sem uma fonte de renda fixa, ela vivia “dependendo dos outros", do que ganhava no labor agrícola e com os R \$22,00 (vinte e dois reais) que recebia do Bolsa Família ${ }^{15}$. Esporadicamente, ela fazia faxinas em casas da cidade. Entretanto, Jennifer elencava os obstáculos que tinha de enfrentar e que a impediam de sair da aldeia onde morava. O maior deles era a necessidade de cuidar de seu irmão menor desde quando este tinha seis anos. Jennifer se referia a ele como se houvesse realmente assumido o papel de mãe.

Jennifer estava cursando a quinta série do Ensino Fundamental. Quanto ao futuro, ela dizia que "aí vai depender dos outros pra arrumar emprego. Se o povo me der alguma coisa, aí posso ir em frente". Enquanto isso, ela conciliava os estudos, os afazeres domésticos e ultimamente atuava como dançarina de uma banda, formada por pessoas da aldeia, que se apresentava ocasionalmente em cidades e povoados próximos. Tornar-se uma estrela famosa era outro de seus sonhos.

Quando pedi para que falasse de sua infância, Jennifer disse que sua vida era "muito complicada", principalmente depois que ela foi "ter relação com um rapaz. Eu era novo demais e ele já era mais maduro. Ele morava vizinho de casa, era índio também”. Ela tinha apenas 7 anos nessa época, enquanto o rapaz "mais maduro" estava com 12. Esse relacionamento foi duramente reprovado pelo pai dela: "Quando pai soube, ele queria botar eu de casa pra fora. Pegou minhas coisas e jogou fora”. Já a mãe - "todas mães têm que apunir [apoiar], né?” - trouxe seus pertences de volta. A contragosto do pai, Jennifer ficou "dentro de casa" com seu namorado. Contudo, passado algum tempo, "pra evitar confusão", este achou por bem voltar para a casa de seus pais, enquanto Jennifer permaneceu na dela. Segundo minha interlocutora, tal relação era do conhecimento de ambas as famílias envolvidas.

Após alguns meses, porém, Jennifer foi novamente expulsa de casa pelo pai, indo morar com o namorado na casa dos pais dele. Depois de dois anos, entre idas e vindas, o relacionamento chegaria ao fim, "porque pai não queria, nem a família dele. Que a família dele ficou intrigada. Teve uma confusão lá e ficaram intrigados. E a gente não teve como 
ficar junto". Desde então, Jennifer decidiu que “nunca vou ter relação com ninguém nem trazer pra dentro de casa".

É interessante observar que o episódio mais marcante de sua infância consistia justamente no momento em que ela percebeu sua atração por homens e em que se deu sua primeira relação sexual. Por volta dos 11 anos, Jennifer começou a usar roupas e acessórios femininos:

Eu fui comprando minhas coisas, comprava devagarinho, comprava maquiagem, comprava batom, comprava qualquer coisa, aí fui me vestindo. Aí todo mundo: "Você tá bonita"; "Você é linda demais"; "Você é a primeira índia que se veste assim". É bom a pessoa se vestir assim. Mas tem uns índio, umas bicha que têm ódio da minha cara porque eu me visto de mulher e eles num pode se vestir. Aí fica criticando.

Segundo ela, sua mãe jamais se mostrou contra o fato dela usar roupas femininas; quanto ao pai, ele "tinha raiva da minha cara por causa que eu sou desse jeito". Contudo, após a morte da mãe, finalmente o pai "se entendeu como gente. Porque ele tá valorizando eu. Porque, depois que mãe morreu, quem faz as coisas de dentro de casa é eu”.

"Ser desse jeito". O que Jennifer queria dizer com isso? Ela lembrava que, ainda criança, sua avó materna "mandou me levar no médico. O médico disse que esse negócio que eu tive era de nascença e que não tinha como voltar atrás. O médico disse: 'Não tem mais jeito, não; já é de nascença’. Aí daí ficou”. Segundo Jennifer:

o povo diz que isso é doença. Uns diz que é porque tem inveja de mulher, porque mulher pega qualquer homem e a gente, que somos desse jeito, não pode pegar. Mas eu acho que não é, não. Porque a gente vai fazer o que a gente pode. Pra viver na vida, tem que ter cada uma coisa diferente. Mas eu acho que já vem de nascença e a gente tem que encarar a verdade.

Sem referir-se a si mesma como homossexual, Jennifer, a exemplo de Britney, dizia sentirse "mais mulher", uma "mulher feliz do jeito que eu sou". Feminina sem a ingestão de hormônios e aplicação de silicone, dizia ter o "sonho de colocar de cada coisa um pouquinho. Se eu pudesse, eu botava".

Inicialmente, Jennifer disse que, exceto o pai e a mãe deste, as pessoas da aldeia não a recriminavam "porque a gente somo índio. Ninguém vai falar prejudicando nem criticando, porque eu sou índio". Com isso ela pretendia informar sobre a preeminência que seu status étnico (na qualidade de "índio") tinha na aldeia onde ela morava. Era como 
se sua indianidade ${ }^{16}$ tivesse o poder de neutralizar o estigma que poderia recair sobre ela em virtude de sua sexualidade e, sobretudo, de sua identidade de gênero. Entretanto, as coisas não eram tão simples assim, pois, em outro momento de nossa conversa, Jennifer acabou por admitir que havia "muito preconceito, tanto aqui como fora do lugar. Tem gente que diz: 'Não tem nem vergonha na cara!’”.

Todavia, o "preconceito" contra ela não impedia que Jennifer tivesse suas aventuras eróticas e afetivas. Ela costumava sair com seus amigos ("motoqueiros") da aldeia e, na companhia deles, ia a bares localizados em municípios circunvizinhos, como Mataraca e Rio Tinto. Não bebia mais, "graças a Deus", mas não dispensava um bom forró. Alguns desses seus "colegas" também eram parceiros sexuais, porém ela não gostava de envolver-se com eles, "porque esses meninos só querem usar e sair. E tem uns que usa e fica falando pelo mundo. Isso eu num gosto”.

Apesar dos relacionamentos afetivos tumultuados, Jennifer dizia que "meu sonho era casar. Se um dia eu tivesse um relacionamento com um homem, e se fosse sério mesmo, eu pretendia casar. Eu comprava as coisa pra ele, eu poderia dar uma casa, um apartamento, qualquer coisa pra ele. Só pra eu viver com ele. Meu sonho é esse”.

\section{Scarlett}

Scarlett tinha 23 anos quando a conheci. Ela nasceu em Rio Tinto, a segunda maior cidade da Microrregião do Litoral Norte da Paraíba, mas, até os 19 anos, morou em Camurupim, uma aldeia Potiguara situada no município de Marcação (porém distante do núcleo urbano deste município), povoado por cerca de 644 habitantes. Ela era fruto da união de uma "branca" e um "índio". Meio a contragosto, Scarlett se dizia "índia", porém com uma ressalva: "Eu não me sinto tanto índia, me sinto mais uma pessoa da cidade. Porque eu não tenho os hábitos indígenas, os costumes de se vestir, dançar, falar as línguas...”.

Ela tinha quatro irmãos. O mais velho, assim como ela, era fruto do primeiro casamento de sua mãe. Os outros três eram filhos desta com outro homem. Quando a mãe se separou do primeiro marido, Scarlett tinha apenas um ano de vida. Por isso, ela praticamente não conheceu o pai.

Até os 11-12 anos, Scarlett atendia pelo nome masculino com o qual havia sido batizada. Foi mais ou menos nessa época que ela teve sua primeira experiência sexual, a qual se deu com um vizinho dela, de 18 anos. Mas antes, por volta dos 7 anos, "eu era gayzinha já, afeminada. Eu gostava muito de brincar de casinha, de boneca com minhas 
irmãs, com minhas amigas. Só brincadeira de menina”. Segundo ela, a assunção de sua sexualidade ocorreu quando ela tinha entre 13 e 14 anos. Quando isto se deu, as palavras de sua mãe foram: "Meu filho, eu lhe dei tanto conselho, e você quis essa vida!". "É, mãe, fazer o quê? Faz parte da vida hoje em dia a homossexualidade", disse Scarlett.

Depois disso, não tardou muito para ela começar a vestir-se com roupas femininas e, desde então, sua relação com o padrasto seria marcada por conflitos. "Meu padrasto nunca me aceitou". As intermináveis discussões entre eles culminaram com a saída de Scarlett da casa da mãe. Ela tinha 15 anos quando foi morar com a avó materna, que também vivia em Camurupim. Após viver um tempo ali, uma briga com um tio materno fez com que Scarlett fosse mais uma vez expulsa. Ela foi morar numa casa cedida por um amigo e, em seguida, num quartinho construído por um outro tio no terreno dela, onde Scarlett vivia ao tempo de minha pesquisa. Em virtude de tantas atribulações, não era de surpreender que Scarlett não guardasse boas recordações de sua infância: "Minha infância foi terrível, foi todo o meu sofrimento de enfrentar a família, a sociedade em geral. Fui enfrentar a vida no meio do mundo".

Aos 19 anos, Scarlett viajou para a Itália, onde viveu por pouco mais de três anos, atuando como garota de programa.

Era maravilhoso! Se eu pudesse voltar, já tinha voltado há tempo. Foi gratificante. Onde eu passei a conviver com o povo da cidade, com outras culturas, outros hábitos. Foi gostoso. Aprendi a viver a vida melhor, diferente daqui; a ser dependente de mim mesmo; aprendi outros idiomas, conheci várias pessoas de vários países como França, Estados Unidos.

Para ela, a experiência vivida na Itália "foi tudo! Uma delícia", porque, além dos belos homens, lá não havia tanto "preconceito" contra homossexuais quanto no Brasil. "Eu acho o Brasil muito preconceituoso ainda. Aqui eu vivi muita discriminação, muito preconceito. E ainda vivo".

Foi na Itália que Scarlett experienciou diversos relacionamentos sexuais e afetivos. "Lá eu conheci o que era ter um relacionamento", disse ela. Um, em especial, marcou-a profundamente. Enquanto trabalhava nas noites romanas, ela conheceu um italiano, filho de brasileira. "Foi amor à primeira vista". Com ele, Scarlett viveu durante cerca de um ano. Apesar disso, em 2009 ela decidiu voltar para o Brasil, "porque eu tava com saudade da família, tava cansada de tanto frio. Deu uma deprê, aí tive que vir embora". Quando a encontrei pela primeira vez, havia-se transcorrido três meses desde o seu regresso à aldeia. 
Ela dizia que em breve embarcaria novamente para a Itália. Um ano depois, porém, quando voltei ao campo, ela continuava em Camurupim, apesar de afirmar não gostar de viver lá. "Eu queria viver na cidade, em Mamanguape, Rio Tinto, João Pessoa, essas cidades por aí. O exterior, se possível. Porque na cidade toda noite tem pra onde você ir, tem tudo".

Por que o projeto de voltar à Itália, que antes parecia iminente, havia se transformado num sonho distante para Scarlett? Teriam sido problemas financeiros, legais ou de outra natureza que a impediram de retornar à Europa? Sobre isso, Scarlett nada falou. $\mathrm{Na}$ verdade, de acordo com alguns amigos dela, Scarlett evitava falar a respeito do lado mais difícil de sua vida. Além de glamourizar sua experiência na Itália, omitindo as dificuldades que enfrentou por lá, ela não detalhava os momentos de sofrimento vividos na aldeia Camurupim.

A passagem de Scarlett pela Itália constitui um dos pontos cegos desta pesquisa. Embora ela tenha contribuído para isso, mostrando-se evasiva sempre que esse tema vinha à tona durante nossas conversas, não insisti para obter maiores informações no intuito de saber como ela chegou até lá, por meio de quem ${ }^{17}$ e com que finalidade. O silêncio de Scarlett sobre esse assunto, portanto, somente poderia ser interpretado conjecturalmente, à luz de pesquisas como a de Patrício (2008) e, principalmente, a de Teixeira (2008). Esta última, com base nos depoimentos de algumas de suas interlocutoras, aponta o "medo de denunciar" as "cafetinas" como uma das principais razões que justificam o silêncio de muitas travestis brasileiras sobre sua passagem pela Europa, sobretudo pela Itália (Teixeira, 2008: 289). Outra explicação poderia ser encontrada na "desilusão" de muitas travestis, constatada por Pelúcio (2005), ao não conseguirem o tão almejado sucesso, traduzido na aquisição de "carros, casas, terrenos" e na transformação feminilizadora do corpo (transformação empreendida graças a implantes de próteses de silicone, procedimentos estéticos como lipoaspiração e depilação a laser; ao uso de "roupas, perfumes, jóias e acessórios de grife”) (Teixeira, 2008: 293-294). Não obstante, a dimensão afetiva não pode ser negligenciada aqui, pois a própria Teixeira (2008: 294) observou que, "também para as travestis, a decisão sobre migrar [ou não] e permanecer [ou não] na Itália pode ser uma estratégia individual de ascensão social, mas é marcada por outras escolhas e projetos, por exemplo, afetivos".

Conjecturas à parte, o certo é que, transcorrido um ano desde seu retorno à Paraíba, Scarlett parecia razoavelmente adaptada à vida na aldeia, retomara os estudos numa escola de Marcação e pretendia cursar Turismo ou Estilismo numa universidade. Ainda que evitasse frequentar a casa da mãe por conta do padrasto, ela dizia contar com a 
ajuda materna e seu discurso, ao menos quanto aos irmãos, adquirira contornos menos dramáticos. "Minha relação com eles é maravilhosa, uma vez que eles não interferem na minha vida. Me respeitam da maneira que eu sou. Eu não sei se dizem alguma coisa por trás, mas, na minha frente, me tratam maravilhosamente".

"Eu me sinto muito bem do jeito que eu sou. Agradeço a Deus por ser assim, e sou feliz", dizia ela, embora, de quando em vez, se queixasse das saudades que sentia de seu exnamorado ítalo-brasileiro. Talvez por isso ela não quisesse se apaixonar novamente, porque "quando você se apaixona, você fica o tempo todo pensando na pessoa. E quando acaba, é mesmo que você levar uma facada. É triste. A paixão é uma coisa tão séria, e hoje em dia são poucos os homens que valem a pena a gente se apaixonar por eles”.

Scarlett havia injetado silicone industrial nas coxas e região dos glúteos. Pretendia ainda "colocar peito", mas, diferentemente de Britney e Jennifer, descartava a ideia de submeter-se a uma cirurgia de transgenitalização, afinal, "eu não me sinto muito homossexual, eu me sinto mais mulher". Curiosamente, porém, Scarlett acreditava não haver diferença significativa entre uma travesti e um homossexual masculino. Segundo ela, somente com uma "operação" para "mudança de sexo" é que se daria uma diferenciação mais contundente. $\mathrm{Na}$ verdade, Scarlett punha em xeque quaisquer distinções demasiado rígidas entre travestis, homossexuais (fossem estes indígenas ou não) e "homens", pois, dizia ela, "todo homem tem sua parte meio homossexual, só que tem medo de fazer com certas pessoas. Tem muitos homens que querem ser passivos; outros são ativos e passivos também".

O fato de Scarlett não vincular mecanicamente feminilidade (gênero), corpo (genitália) e sexualidade (orientação sexual) ilustra aquilo que Arán e Peixoto Júnior (2007: 134), apropriando-se das considerações de Butler (2003), afirmam, isto é,

a nomeação do sexo é um ato performativo de dominação e coerção que institui uma realidade social através da construção de uma percepção da corporeidade bastante específica. A partir dessa perspectiva pode-se entender que o gênero é uma "identidade tenuamente construída através do tempo" por meio de uma repetição incorporada através de gestos, movimentos e estilos.

Os autores ponderam ainda que, "[s]e o gênero é uma norma, não podemos deixar de lembrar o que há de frágil na sua incorporação pelas subjetividades. Há sempre uma possibilidade de deslocamento que é inerente à repetição do binarismo masculinofeminino" (Arán e Peixoto Júnior, 2007: 135-136). Se pensarmos à luz de tal perspectiva 
teórico-analítica, é compreensível entender o fato de Scarlett não sentir-se menos feminina em virtude de uma não intervenção cirúrgica em seu corpo. Bento (2006: 22) nos informa que "[a] radicalização da desnaturalização das identidades, (...) apontará que a identidade de gênero, as sexualidades, as subjetividades só apresentam uma correspondência com o corpo quando é a heteronormatividade que orienta o olhar" (Bento, 2006: 25).

Entretanto, se, para Scarlett, a presença ou ausência da genitália masculina ou feminina seria incapaz de definir por si só identidades de gênero, promovendo uma distinção radical entre "travestilidade", "transexualidade", "feminilidade" e "homossexualidade", para ela, a orientação sexual, ou, melhor dizendo, o desejo erótico por sujeitos do mesmo sexo biológico, tampouco era suficiente para estabelecer uma fronteira clara e fixa entre pessoas "homo" ou "heterossexuais". De acordo com suas palavras, embora tênue, o principal índice de diferenciação residiria nas práticas sexuais, ainda que o significado atribuído às mesmas dependesse em alguma medida da identidade de gênero e da subjetividade dos sujeitos envolvidos na interação social/sexual.

\section{Lindsay}

Scarlett tinha uma prima, também travesti, chamada Lindsay, a quem conheci no mesmo período. Lindsay tinha 24 anos, nasceu em Camurupim, mas até os cinco anos viveu com os pais (um casal de agricultores) numa outra aldeia, também situada no município de Marcação. Lindsay tinha seis irmãos, três do sexo masculino e outros três, do feminino. Embora apenas seu pai fosse por ela definido como "índio", Lindsay se autodenominava indígena.

A infância de Lindsay "foi um pouco ótima", até o dia em que "eu virei homossexual". Segundo ela, "a família era tudo preconceituosa e não aceitava". Nesse período, a convivência com seus pais biológicos tornara-se bastante difícil, e Lindsay era constantemente surrada por eles. Assim, aos cinco anos ela foi morar com a avó paterna (que era também avó de Scarlett). Desde então, ela teve pouco contato com os pais e irmãos. O pai "tinha ódio de mim; preferia ver o demônio de que ver eu; depois que eu virei homossexual. Era preconceito demais! Eu não gosto de painho, nem de mãe. Ela também não gosta de mim”.

Refletindo sobre sua sexualidade, Lindsay dizia que "sempre eu fui. Quando eu era criança, eu brincava de esconde-esconde. Antes de eu namorar, já fazia o que não devia. Eu tinha uns 8, 10 anos". Aos 12, ela teve sua primeira experiência sexual com um primo 
de 20 anos, irmão mais velho de Scarlett: "Foi ótimo! Ele entrou dentro de casa e me pegou à força. Na hora eu ia correr, mas não deu pra mim correr”. Quando tinha entre 14 e 15 anos, porém, "pra mãe não descobrir, eu comecei a namorar com mulher, mas só que eu não gostava muito de mulher. Aí depois eu tomei uma decisão: ou homem ou mulher”. Antes de tomar esta "decisão", ela namorou, durante um ano, uma garota a quem Lindsay disse ter amado "demais. Ela também me amava". Segundo ela, o namoro terminou “porque a mãe dela não aceitou, depois que descobriu que eu era gay”.

Até os 18 anos, Lindsay atendia pelo nome de batismo, embora já usasse roupas femininas. Numa reunião entre ela, Scarlett e duas amigas travestis que moravam em Rio Tinto, "todo mundo começou a botar os nomes de guerra, aí eu botei o meu". Desde então, ela era chamada por todos, inclusive pelos familiares, pelo seu "nome de guerra". Mas a relação de Lindsay com travestis de Rio Tinto e Mamanguape significou para ela bem mais do que a adoção de um nome e uma persona femininos. Aos 20 anos, graças a estas suas amigas, ela foi trabalhar num "cabaré" em Mamanguape, onde atuou como garota de programa durante seis meses. Em seguida, foi para um pequeno município norterio-grandense, onde trabalhou, por outros seis meses, noutro "cabaré". Lindsay lembrava esta época com saudades: "Era ótimo! Os homens tudo me adoravam. Eu gostava, e gosto". Segundo ela, dava para ganhar dinheiro suficiente para comprar suas "coisas" (ela ganhava em média trinta reais por programa).

Em 20 de novembro de 2006 (data recordada com precisão), Lindsay embarcou rumo à Itália, onde pretendia trabalhar como profissional do sexo. Lamentavelmente, ao desembarcar em Portugal, ela foi "transportada de volta".

Lindsay acabou por abandonar a prostituição, a vida em outra cidade e o projeto de viver na Europa porque começou a sentir saudades de sua avó, mas, sobretudo, porque ela conheceu Netinho, um jovem natural de outra aldeia, que viria a ser seu "esposo". Lindsay e Netinho se conheceram no carnaval de 2004. "Foi um amor à primeira vista, bem na doideira", disse ela. "Desde essa primeira vez eu me apaixonei por ele". Essa relação, contudo, foi e continuava sendo bastante atribulada. Num primeiro momento, porque os pais do rapaz não admitiram o relacionamento entre eles. De acordo com Lindsay, o pai de Netinho "tentou me matar de facão" e chegou a denunciá-la ao Conselho Tutelar, já que, à época, Netinho era menor de idade (o caso só não foi adiante porque Netinho deixou claro que gostava dela). Antes de seu envolvimento com o rapaz, Lindsay se dava bem com os familiares dele, que viviam em Camurupim. Contudo, "agora eles não falam mais comigo, não tenho mais nenhum contato". 
Outro problema eram as brigas e agressões físicas entre eles, geralmente motivadas por ciúmes. Lindsay admitia dar "motivos" para isso. Seus amigos mais próximos a aconselhavam a abandonar seu companheiro, acreditando que, mais cedo ou mais tarde, uma tragédia se daria. Apesar disso, Lindsay dizia amar Netinho, levar "uma vida de casada" e gostar de "respeitar meu esposo. Antes eu saía, botava muito chifre nele. Mas agora, jamais!". Para ela, o melhor de viver casada era "ter Netinho sempre ao meu lado. E eu não trabalho, ele que procura as coisas pra me manter". Netinho ganhava a vida auxiliando o pai no labor agrícola. Quanto a Lindsay, ela cuidava dos afazeres domésticos e do pequeno roçado que cultivava no quintal de sua casa.

Preocupada com a falta de um trabalho que lhe assegurasse uma renda fixa, Lindsay acreditava que, para os índios, ainda mais se estes fossem homossexuais ou travestis, tudo era mais difícil, sobretudo para conseguir emprego. "Tem muito preconceito aqui no Brasil. Mais com pessoas que usam roupa de mulher, travesti. É mais difícil pra conseguir as coisas. Eu acho que, se eu não fosse homossexual, eu tinha meu trabalho".

Viver casada, porém, de acordo com Lindsay, tinha inúmeras desvantagens. Primeiro, "porque a família dele [Netinho] me detesta". Segundo, porque "a pessoa fica presa, não sai muito; vive mais dentro de casa". Pensando nesses inconvenientes, Lindsay afirmava que "eu não queria me casar mais, queria só viver curtindo a vida. É o que eu gosto". Mas por que ela continuava com Netinho? Seria porque ele a sustentava? Provavelmente não, já que a própria Lindsay queixava-se frequentemente pelo fato de Netinho gastar todo seu dinheiro com bebida, deixando a cargo dela pôr comida na mesa. Seria então por conta do amor? "Eu amo, eu gosto muito dele. E até hoje nós estamos juntos. Brigamos muito. Mas, se ele não fizer nada de errado, sempre vamos estar juntos, até a morte nos separar".

Lindsay e Netinho procuravam reproduzir um tipo de união heteronormativa, onde uma exercia, para todos os efeitos, o papel de "mulher", e o outro, o de "homem". Por sinal, ainda que em diversos momentos se referisse a si mesma como homossexual, Lindsay se considerava "mulher". "Eu acho que falta só botar silicone no corpo, se transformar todinha mesmo numa mulher. Só isso mesmo". Às vezes ela se pegava sonhando com uma possível "mudança de sexo", para logo descartar a ideia, temendo que algo desse "errado". Apesar de haver aparentemente uma dicotomia de gênero na relação estabelecida entre Lindsay e Netinho, não havia, quanto às suas práticas e trajetórias sexuais, uma divisão tão clara. Primeiro porque nem sempre Lindsay era a "mulher no sexo", tampouco Netinho era o "homem" simplesmente. De acordo com ela, ambos 
tinham prazer "por igual", fazendo "tudo" (o mais importante aqui é que as identidades de gênero mantinham-se intactas). Segundo porque Lindsay, além de ter experimentado sexo com mulheres, dizia-se atraída por homossexuais e haver se relacionado com alguns. Nesse aspecto, portanto, ela se diferenciava da maioria de meus interlocutores e interlocutoras, para quem a relação sexual envolvendo duas "bichas" se constituía num tabu. Netinho, por sua vez, ao longo de sua trajetória sexual, relacionou-se com homens homossexuais.

Por outro lado, tal flexibilidade, responsável pela desvinculação entre práticas sexuais e identidades de gênero, não levava Lindsay a solapar quaisquer distinções entre homossexuais e "homens": "São diferentes, porque homem que é homem jamais vai querer ser igual a homossexual". Ademais, para ela, se o primeiro interagisse sexualmente com outro na condição de sujeito "passivo", este seria, "por debaixo dos panos", um homossexual "abafado", "não assumido"18.

Quando conheci Lindsay, ela estava morando com Netinho numa casinha de taipa cedida pelo tio dela. Antes, o casal vivia se encontrando nas matas da aldeia, onde passaram várias noites ao relento. Um ano depois, num terreno cedido pelo cacique de Camurupim, ela construiria sua casa própria, também de taipa. Todavia, o processo de concessão do terreno e da verba governamental para a construção de uma casa de alvenaria foi para Lindsay uma demonstração explícita de discriminação contra ela e Netinho, pois alguns moradores da aldeia (entre eles o cacique) diziam que tal verba era destinada às famílias mais "carentes" e que Lindsay e Netinho não poderiam ser contemplados por não constituírem uma "família". No final das contas, Lindsay não foi beneficiada e o sonho de ter uma casa feita de tijolos acabou sendo adiado.

Tal fato poderia ser atribuído ao faccionalismo e às disputas políticas existentes em Camurupim e nas demais aldeias Potiguara, o que reverberava no favorecimento de pessoas ligadas às lideranças locais em detrimento do prejuízo e da exclusão de pessoas de facções rivais. Entretanto, de acordo com Lindsay e seus amigos, no final das contas imperou a discriminação contra ela, em virtude de sua sexualidade e de sua identidade de gênero, e, consequentemente, no não reconhecimento de seu relacionamento com Netinho, pois, ao fim e ao cabo, a percepção compartilhada socialmente de que Lindsay era um homem biológico ensejou o argumento de que ela e Netinho não formavam um "verdadeiro casal". 


\section{Naomi}

Um dia, na casa de Lindsay, conheci Naomi, uma travesti de 21 anos natural da aldeia Jaraguá (povoado de 699 habitantes, situado no município de Rio Tinto), local de origem de seus pais, um casal de agricultores indígenas. A exemplo de Scarlett, Naomi teve pouco contato com o pai (falecido quando ela tinha 15 anos), cuja esposa resolveu separar-se dele em virtude de seu vício em jogo e álcool. Naomi tinha apenas dois anos quando isto aconteceu. Ela era a segunda de cinco filhos ("tem uma mulher; um efeminado, que sou eu; e tem mais três machos, homens mesmo"), dos quais três continuavam morando na casa materna. Apesar de sua indianidade, ela não se preocupava com o movimento indígena, "com nada. Sou liberal".

Naomi descobriu o sexo com apenas cinco anos, graças a um homem que mais tarde viria a ser padrasto dela. "Logo no começo, que eu era pequenininha, ele vinha tendo relação comigo". Embora dissesse que "ele que vinha incentivando", Naomi fez questão de completar: "Eu não vou mentir, eu gostei. Não me senti abusada, não". Ao longo dos dez anos seguintes, eles continuariam mantendo um "caso" sem o conhecimento da mãe de minha interlocutora. "E até hoje ela não sabe". De acordo com Naomi, ainda que soubesse, a mãe não acreditaria nela, porque "ela é louca, apaixonada por ele. Ele faz o que quer com ela". Aos 15 anos, Naomi chegou à conclusão de que "isso tá errado. Porque ele fica com minha mãe e tem relação comigo". Ao decidir pôr um fim à relação com o padrasto, a convivência com ele ficou "péssima". "E até hoje ele tem ódio da minha cara, porque eu não quis mais ele". A partir daí, sua vida dentro de casa tornou-se insustentável e Naomi teve de "pegar o beco". "E hoje eu vivo no meio do mundo, passando necessidade".

Quando a conheci, ela estava morando em Salema, distrito rural de Rio Tinto. Sua saída de casa, porém, fora motivada não apenas pelas desavenças com o padrasto e ex-amante, mas "por causa do preconceito", inclusive da mãe, que a "xingava muito; separava colher, garfo, faca, prato, copo, com nojo de mim porque eu sou homossexual, travesti. Parecia que eu tava até com AIDS, uma doença que pegasse, que não tivesse cura”. Não era à toa, portanto, que, ao discorrer sobre a infância, Naomi dissesse que:

nunca foi boa minha vida. Porque, desde criança, o povo olhava pra mim e dizia: "Ah, esse daí vai ser um gay". Todo mundo falava por uma boca só. Fiquei na rua, passei muita fome por causa disso. Mandaram eu cortar meu 
cabelo, me botaram no Conselho Tutelar pra eu deixar essa vida de travesti. Mas não é por causa disso que eu vou deixar de ser.

A reação dos irmãos, sobretudo do mais velho, a princípio não foi diferente. Segundo ela, este "tinha ódio de viado, tinha pavor. Queria bater em neu e tudo. Porque ele queria que eu virasse homem à força, uma coisa que eu não sou. Se eu fosse besta, baixasse a cabeça, ele batia em neu. Só que eu pegava e metia-lhe o pau”.

Aos 18 anos ela começou a vestir-se com roupas femininas e, aos 19, passou a ingerir hormônios. De um estágio a outro, ela deixou de ser apenas "traveco" para tornar-se uma "travesti", a qual ela definia como "homem e mulher ao mesmo tempo". Era por isso, de acordo com ela, que os "machos" gostavam de travestis. Porém, não de todas. Para Naomi, muitos "machos" discriminavam "viados", ainda mais se estes fossem "travecos feios, que não têm aparência de mulher". Nesse ponto, ela fazia questão de distinguir-se, enfatizando sua feminilidade e beleza. "Os macho pensa que eu sou uma mulher. E cada vez que passa, mais mulher eu quero ficar”. Graças a seus atributos físicos, ela se dizia feliz, ainda mais porque:

a hora que eu chego num canto, se tiver um homem, eu consigo. Tudo é mais fácil pra mim. Por isso eu decidi tomar hormônio, porque é um meio de passagem. Você passa num canto, todo mundo respeita você, não é criticado de "viado feio". Todos querem tirar uma casquinha. Eu só sou bonitinha assim por causa dos hormônios.

Além da ingestão de hormônios, ela pretendia aplicar silicone nos seios, "botar umas coxa maior, mais grossa; usar lentes de contato, umas coisa chique", em suma, "me ajeitar mesmo, investir na minha beleza". Quanto a submeter-se a uma cirurgia de transgenitalização, Naomi era taxativa: "Não. Deixa eu aqui mesmo, que eu adoro. O bom é isso, eu vou tirar?! Nunca!”.

Naomi não queria "tirar" porque ela gostava de "fazer tudo" no sexo, principalmente "comer". Tal gosto não significava que Naomi interagisse sexualmente com "viado, homossexual mesmo". Ela se sentia atraída por e obtinha prazer com "macho mesmo", ainda que estes fossem "viados encubados" ou não "revelados". Para Naomi, o "passivo" sexual era "viado", já que "homem que é homem não vai deixar um travesti comer ele. E a maioria dos homens hoje pede pra eu comer. Muito raro eu não fazer essa linha". As palavras de Naomi deixavam claro que, para além das práticas sexuais, o que importava eram as performances de gênero dos indivíduos. Não fosse assim, ela não 
interditaria o sexo com outros "viados". Seu discurso apenas reiterava o peso relativo que a atividade sexual desempenhava na definição que alguns sujeitos elaboram sobre identidades de gênero. Ou seja, nem sempre sexo e gênero apareciam entrelaçados.

Concordo, portanto, com Pasini (2009: 244), quando esta afirma que

(...) sabe-se que a sexualidade não trata apenas de atividades sexuais, da genitália, das fantasias, dos desejos sexuais ou dos comportamentos dos sujeitos, mas também trata da personalidade, do sentimento, da sensação, dos limites, do pensar, do sentir, das convenções, do conhecer-se e das conexões sociais. Portanto, só é possível compreendê-la a partir de práticas corporais, sexuais e sociais. (...) A sexualidade de um sujeito não é previamente ou naturalmente estabelecida e de forma alguma está fixa em um corpo, em uma maneira de ser e de se expressar. Por tudo isso, ela só adquirirá significado quando compreendida sob um determinado contexto cultural e histórico, a partir de uma situação específica, a partir dos sentidos ali elaborados.

Continuando a falar sobre sexo, Naomi afirmou haver tido, ao longo de sua trajetória afetiva, muitos parceiros. Um destes se destacava porque com ele Naomi namorou durante três anos. O rapaz também vivia em Salema, e Naomi chegou inclusive a morar na casa dos pais dele. "Eu era louca por ele, amava aquele homem". O amor, porém, viria a acabar “de repente”. Quando encontrei Naomi para ouvir sua história, havia oito meses que ela rompera o relacionamento com o rapaz. "Ele tava bebendo muito, a família dele era muito encrenqueira, aí não deu certo, deixei pra lá”. Além disso, o jovem a agredia fisicamente. Como prova, Naomi mostrou uma cicatriz em seu pescoço, sinal de um corte de faca. "Se eu fosse um viado mole, ele já tinha me matado. Só porque na minha mão o macho dança. Só porque ele acha que eu sou travesti, mas eu sou o mesmo homem. Eu sou mais homem de que ele. Porque o homem que teve coragem de se revelar ali é o mais corajoso do mundo: o travesti, o homossexual".

Outra razão que levou Naomi a separar-se de seu companheiro estava relacionada à associação feita por ela entre "amar" e "sofrer". "Quando eu comecei a sofrer por ele, eu disse que ia tentar esquecer. Eu sou muito sabida, quando eu vejo que eu tô me apegando a uma pessoa, eu já corro pra cima de outro, já pra esquecer aquele. Gosto de me apegar, não. Posso me apegar, se ele quiser uma coisa séria comigo. Aí eu me entrego geral”.

Naomi tinha "colegas" travestis que viviam em João Pessoa, Natal, Recife e na Itália. Por falar nisso, ir para a Itália constituía um de seus grandes projetos de vida, "porque lá eu acho que vou arrumar alguma coisa, vou ter uma vida melhor, um futuro melhor". Na Itália, Naomi pretendia se "prostituir, fazer programa. Que lá eu tenho certeza 
que vou arrumar meu meio de vida. Lá eu quero casar, arrumar um italiano, ficar pra lá mesmo". Quando perguntei se ela já havia feito programa, Naomi respondeu: "Não vou pra pista, mas já fiz um programa”, o qual lhe rendeu $\mathrm{R} \$ 30,00$ (trinta reais). Ela dizia receber convites para emigrar, e que tinha "um colega, uma bicha de São Paulo, que ficou de me levar pra São Paulo, de lá manda pra Itália”.

\section{Travestilidade, etnicidade e... prostituição?}

A fala de Naomi, somada ao fato de Scarlett ter vivido na Itália e Lindsay haver se prostituído em Mamanguape e no Rio Grande do Norte, levou-me a refletir sobre a dinâmica, a recorrência e o significado que a prática prostitutiva apresentava no contexto pesquisado e para minhas cinco interlocutoras, mas a insuficiência de informações não me permite avançar nessa discussão. O fato é que, à época desta pesquisa, nenhuma delas se prostituía. Mas é digno de nota que aquelas que exerceram em algum momento de suas vidas atividade sexual remunerada viveram em Rio Tinto ou Mamanguape, ou mantinham vínculos com pessoas (incluindo travestis e garotas de programa) desses dois municípios, que, em termos espaciais, demográficos e econômicos, eram significativamente maiores do que Baía da Traição e Marcação, havendo mais dinheiro circulando, mais emprego e geração de renda, além de um trânsito maior de pessoas que para lá acorriam em busca de trabalho, lazer e estudo ${ }^{19}$.

Isto confirmaria as teses defendidas por autores como Kulick (2008: 152) e Hélio Silva (2007: 63), para quem as travestis brasileiras são, no final das contas, "fruto histórico do asfalto e das grandes aglomerações urbanas"? Não necessariamente. Minhas cinco interlocutoras, além de colocarem em xeque a associação automática entre travestilidade e urbanidade, rebatiam um outro tipo de associação, desta vez envolvendo beleza, feminilidade e valorização no "mercado sexual", tal como defendida por Kulick (2008: 100107, 159). No caso de minhas interlocutoras, mesmo no de Naomi, que tomava hormônios, o desejo de serem belas e femininas contava bem mais do que a possibilidade de virem a "lucrar" financeiramente com isso. Nesse sentido, beleza e feminilidade extrapolavam imperativos mercantis, devendo sua premência à vontade delas de serem felizes consigo mesmas. Além disso, mesmo nos casos de Scarlett e Lindsay, que destacaram os momentos de prazer, felicidade e satisfação proporcionados pela prostituição, o papel desempenhado pelo dinheiro na promoção de tais sentimentos e sensações deve ser relativizado. 
E o que estava por trás do "sonho italiano" nos casos de Scarlett, Lindsay e Naomi? A fuga do preconceito, o anseio pelo anonimato, o caminho "natural" a ser seguido, uma vez que "a cidade é o mundo social próprio ao homossexual" (Bech, apud Eribon, 2008: 33-34)? Por que a Itália e não outro lugar fora mencionado por minhas interlocutoras? Estaríamos diante de uma rede de "tráfico" ou "turismo" sexual transnacional? Ora, para além dos dramas e "pânicos morais", das batidas policiais e mortes violentas, da exploração sexual e outras atividades consideradas "ilegais", dos endividamentos e ameaças constantes de deportação, a literatura a que tive acesso (Silva, 2007; Patrício, 2008; Teixeira, 2008) revela uma dimensão menos fatalista e sombria da migração de travestis brasileiras para países europeus como Itália (cf. Teixeira, 2008) e, mais recentemente, Espanha (cf. Patrício, 2008). Conforme Silva (2007: 71), "[e]sses países", além de "euros", conferem a elas "língua estrangeira, requinte, délicatesse"; ou seja, para além das necessidades mais prementes (ganhar a vida, “casar com um italiano"), da violência simbólica sofrida cotidianamente, da falta de oportunidades e privações econômicas (o que certamente impelia muitas travestis a buscarem uma vida melhor), migrar para a Europa significava ascender socialmente. Tornar-se "distinta", contudo, encontrava sua razão de ser no Brasil, mais especificamente no local de moradia de minhas interlocutoras. Não era por acaso que Scarlett, a única a ter tido a oportunidade de viver na Itália, procurasse glamourizar sua experiência, acionando palavras em italiano e omitindo os aspectos negativos de sua passagem pelo estrangeiro. Seu esforço de performar ares de sofisticação, portanto, se dava em meio a pessoas próximas a ela. Mais que agregar "valor ao seu corpo" nas interações sexuais, sua experiência na Itália contribuiu para que Scarlett construísse não uma identidade de gênero distinta das de Britney, Jennifer, Lindsay e Naomi, mas a envolvesse numa aura de requinte e cosmopolitismo.

Todavia, para além da prostituição, o mais importante aqui é entender em que medida a indianidade/etnicidade de minhas interlocutoras importava no incremento do capital simbólico das mesmas no âmbito das relações sexuais e afetivas e na constituição de suas subjetividades. Considerando suas falas, a resposta é simples: nada ou muito pouco. Todas elas, ao serem instadas a respeito de uma possível distinção entre travestis e/ou homossexuais indígenas e "brancos", e sobre uma possível erotização dos primeiros em relação a estes, afirmaram não haver qualquer diferença, para o bem ou para o mal, uma vez que, segundo Naomi, "o que eles têm, também eu tenho. E o que ele gosta de fazer, também eu faço". 
Tal questão tem sua razão de ser, afinal, conforme Harding (apud Stolcke, 1993: 23), por exemplo, em sociedades altamente estratificadas social e racialmente, sobretudo aquelas com um passado colonial e escravista, como a brasileira, "gênero é também uma categoria racial e raça uma categoria de gênero". Desigualdades sociais, de gênero e sexo foram construídas e naturalizadas historicamente para perpetuar desigualdades, afirma Stolcke (1993: 30). Segundo Moore (2000: 34-35), as estruturas de poder se fundam em distinções raciais que são muitas vezes utilizadas para sobredeterminar e substituir outras formas de diferença. Assim, os idiomas de gênero e raça são usados para ordenar diferenças de poder e/ou prestígio, em que o próprio poder é representado em muitos contextos como sexualizado e racializado, engendrando uma masculinidade e um racismo hegemônicos, ligados à ascensão do poder econômico e político, sendo parte de um discurso ocidental sobre o "outro" (cf. Nagel, 2003; Young, 2005). Ironicamente, porém, na contemporaneidade, ao menos no caso dos índios vivendo no Nordeste brasileiro, o que se deu foi uma completa disjunção entre o discurso étnico e questões referentes a gênero e, principalmente, sexualidade. Houve - o que não deixa de ser compreensível em termos políticos - uma produção abundante enfocando o primeiro termo desta equação e um total apagamento de outras instâncias da vida social desses coletivos.

Uma resposta possível para tal fenômeno disjuntivo, responsável pela separação entre etnicidade e certas sexualidades, identidades de gênero (e as travestilidades, que é o que mais nos interessa aqui), possa ser encontrada no próprio campo teórico acerca das etnicidades. Autores como Cohen (1978), Okamura (1981) e Eriksen (1991), por exemplo, estão entre aqueles que, de certo modo, levaram às últimas consequências a dimensão situacional do fenômeno étnico por contemplarem, além dos aspectos estruturais e interacionais, o lado "cognitivo", "subjetivo" contido na etnicidade. Okamura (1981) pensa nos atores individuais e no modo como cada um organiza e atribui significado à sua identidade étnica de acordo com as relações sociais estabelecidas em situações específicas. Sendo assim, o autor destaca a "dimensão cognitiva da etnicidade", isto é, as "percepções e entendimentos do ator" quanto aos "símbolos e signos culturais" (Okamura, 1981: 465). Seguindo esta perspectiva teórico-metodológica, a relevância conferida pelo indivíduo à sua identidade étnica variaria de acordo com cada situação interativa. A partir de um nível "mais baixo" de escrutínio, vemos que o componente étnico - bem como quaisquer marcadores identitários - é fluido, apresentando significados e sendo definido a partir de critérios variados. Sem desconsiderar a importância dos "status relativos, políticos e sócioeconômicos dos grupos, a distribuição das ocupações, a educação, a renda e outros 
recursos materiais e sociais", em suma, a dimensão estrutural, Okamura (1981) observa, contudo, que nem sempre a etnicidade importa nas mais distintas situações sociais. "Pode ser que em algumas a etnicidade seja um fator relevante que influencia a interação das partes, enquanto em outras situações a relação prossiga de acordo com outros atributos, tais como classe, religião, ocupação, sexo, personalidade, etc.” (Okamura, 1981: 452-458). Nesse contexto, ao invés de enfatizar sua identidade étnica, o ator pode simplesmente obscurecê-la, renunciá-la, manipulá-la, optando por enfatizar outros aspectos identitários.

Certamente a questão de realçar ou apagar a identidade étnica não depende apenas da escolha individual dos sujeitos, mas também de fatores objetivos, dos "contextos nos quais as interações se situam" (Poutignat e Streiff-Fenart, 1998: 166-168), da posição ocupada e do status de cada ator. Isso não implica, porém, negar o poder reflexivo, cognitivo e emocional dos sujeitos. É isto o que Cardoso de Oliveira (2006: 79) procura mostrar retomando o termo "identidade renunciada", cunhado por Erik Erikson (1972), isto é, "uma identidade latente que (...) a qualquer momento pode ser atualizada, invocada". "Invocar" ou "renunciar" a uma identidade tem a ver com "ações providas de razoável taxa de racionalidade", afirma Cardoso de Oliveira (2006: 80-81), mas também com a "liberdade do sujeito ético", diz o autor, desta vez inspirado em James Laidlaw (2002). Trata-se, portanto, da "liberdade de uma decisão refletida", da "possibilidade de escolha do tipo de self que [o indivíduo] deseja ser” (Laidlaw apud Cardoso de Oliveira, 2006: 83-84).

Contudo, prestando atenção nos enunciados de minhas interlocutoras, a equação envolvendo sexualidade e etnicidade muitas vezes se traduzia por meio de noções atinentes à "classe", "espaço" e "estilo de vida" (Bourdieu, 2007). Nesse sentido, as noções de classe e estilo de vida apareceram amalgamadas. De modo geral, para minhas interlocutoras, os homossexuais não-índios viviam nas cidades grandes, tinham dinheiro e liberdade, viajavam, conheciam muitas pessoas e lugares. Quanto aos índios, estes eram pobres, viviam isolados nas aldeias; não tinham acesso à informação; desconheciam seus "direitos" e o que era experienciar um relacionamento amoroso "de verdade". Assim, tínhamos dicotomias multissituadas, porém atravessadas, do tipo: urbano/rural, rico/pobre, informados/desinformados; entre os que tinham mobilidade e aqueles (que se sentiam de certo modo) fadados ao imobilismo; entre os que gozavam de liberdade (inclusive para amar o mesmo sexo) e aqueles desprovidos de tal "direito". 


\section{Considerações finais}

O presente artigo não teve como escopo esgotar uma discussão ainda em aberto. $\mathrm{Na}$ verdade procurei trazer aqui algumas questões sobre as quais venho me debruçando e abrir um espaço de diálogo com futuros(as) pesquisadores(as) interessados na abordagem das sexualidades e relações de gênero em cenários que não o urbano. Antes de concluir, porém, considero importante insistir num aspecto referente às categorias acionadas por minhas interlocutoras para qualificarem a si mesmas ou aos outros em termos sociossexuais. Ainda que as tratasse como "mulheres" (pensando que era assim que elas gostariam de ser tratadas), em diversos momentos elas empregaram categorias como "gay", "homossexual", "viado", "travesti" de modo autorreferencial Não obstante as variações semânticas e biográficas, em linhas gerais, para elas, estas palavras diziam algo de suas identidades, as quais começaram a ser construídas a partir mesmo do "nascimento": “A gente nasce homossexual". Frases do tipo: "Homossexual é homossexual; independente de raça, povo, etnia, crença, cultura", sintetizavam a maneira através da qual elas interpretavam as sexualidades "dissidentes". O fato de utilizarem um sistema classificatório semelhante ao que encontramos em outros contextos socioculturais Brasil afora poderia causar estranhamento, caso ignorássemos o fato de que os Potiguara, assim como muitos dos habitantes do Litoral Norte paraibano, não viviam em um cenário isolado. Ora, como escreveu Pacheco de Oliveira (1999: 99), as populações indígenas da região Nordeste do Brasil apresentam um "baixo grau de distintividade cultural", isto é, em virtude do longo e contínuo contato com a sociedade envolvente, estas populações não apresentam hábitos, costumes completamente distintos dos das populações com quem interagem e convivem cotidianamente. Além disso, todas as minhas interlocutoras tinham algum grau de instrução, aparelhos de televisão, telefones celulares e algumas eram membros de redes sociais na internet.

O papel desempenhado pelos meios de comunicação e informação emergiu, no decorrer do trabalho de campo, como uma questão a ser mais bem investigada. Há uma literatura instigante dedicada ao assunto, na qual se destaca a importância que a mídia e o consumo de determinadas imagens têm para a constituição de identidades que extrapolam fronteiras geográficas e culturais. Canclini (1999: 172-173), por exemplo, observa que questões de identidade social e/ou pessoal muitas vezes são respondidas pelo consumo de bens e dos meios de comunicação de massa. A partir da disseminação de imagens por meio da mídia, assistimos e vivenciamos a emergência de comunidades transnacionais de 
consumidores. Não se trata de meras cópias ou de processos homogeneizantes, mas do fato de que narrativas e identidades são coproduzidas (cf. Appadurai, 1994; Friedman, 1994; Hannerz, 1997; Canclini, 2007).

Retomando a tese de uma suposta "homossexualização global", defendida por Altman (1996), Parker (2002: 28) acredita que "as diversas subculturas gays que tomaram forma no Brasil urbano devem ser interpretadas como uma reação complexa e multifacetada às estruturas e condições locais e aos fluxos em transformação que caracterizam o final do século $\mathrm{xx}$ ". Independentemente de o mundo estar mais "homossexualizado" ou não, o fato é que os enunciados emitidos por minhas interlocutoras ilustravam o sentimento de coletividade destes indivíduos em relação a todos os homossexuais, um "pertencimento aceito e assumido", como diria Eribon (2008: $78,181)$.

Segundo Gupta e Ferguson (1992), no tempo presente "o espaço foi reterritorializado" graças à mobilidade das pessoas, à produção e distribuição da cultura de massa (filmes, televisão, jornais, música, internet, etc.), o que erodiu particularidades culturais relacionadas a um lugar, sem levar, contudo, à temida homogeneização cultural global. Levarmos em conta este aspecto nos auxilia na compreensão do porquê de certas categorias e noções correntes nas grandes e médias cidades brasileiras se fazerem presentes no contexto aqui enfocado. Todavia, como diria Geertz (2000), num momento histórico caracterizado pela "suavização do contraste cultural", pela flexibilidade de espaços e identidades, onde o semelhante e o diferente não ocupam territórios exclusivos, é no fortalecimento da nossa capacidade de imaginação para apreender o que está diante de nós que residem os usos da diversidade e de seu estudo.

\footnotetext{
1 Doutor em Antropologia Social pelo Museu Nacional/UfrJ. Pesquisador associado do Laboratório 2 A Microrregião do Litoral Norte do estado da Paraíba, próxima à divisa com o estado do Rio Grande do Norte, compreende os municípios de Baía da Traição, Marcação, Rio Tinto, Capim, Cuité de Mamanguape, Mamanguape, Curral de Cima, Itapororoca, Jacaraú, Mataraca e Pedro Régis.

${ }^{3}$ Autoras como McClintock (2010), Brah (2006), Brah e Phoenix (2004) apontam para o rendimento analítico obtido graças à percepção da conjunção ou interseccionalidade envolvendo diversos marcadores de diferenciação social tais como classe, raça/etnia, crença, gênero e sexualidade (cf. Facchini, 2009: 314-316).

${ }^{4}$ As aldeias ou povoados da Terra Indígena Potiguara (Baía da Traição) são: Akajutibiró, Bento, Cumaru, Forte, Galego, Lagoa do Mato, Laranjeira, Santa Rita, São Francisco, Silva, Tracoeira, Vila São Miguel.
} 
5 As aldeias ou povoados da Terra Indígena Jacaré de São Domingos (Marcação) são: Brejinho, Caieira, Camurupim, Cândido, Carneira, Estiva Velha, Grupiúna, Jacaré de César, Jacaré de São Domingos, Lagoa Grande, Tramataia, Três Rios, Val, Ybyküara.

${ }^{6}$ As aldeias ou povoados da Terra Indígena Potiguara de Monte-Mór (Rio Tinto) são: Vila Monte-Mór, Jaraguá, Silva de Belém e Boréu.

${ }^{7}$ Região que compreende os estados do Piauí, Ceará, Rio Grande do Norte, Paraíba, Pernambuco, Alagoas, Sergipe e parte do estado da Bahia, onde vivem mais de 40 coletividades indígenas (Palitot: 2).

8 O contato com minhas cinco interlocutoras se deu a partir do momento em que me inseri em redes compostas por indivíduos autodenominados homossexuais e que viviam em aldeias ou nos núcleos urbanos dos municípios de Baía da Traição e Marcação. O material etnográfico foi obtido tanto em encontros informais quanto através de entrevistas gravadas que seguiram um roteiro semiestruturado. Algumas destas entrevistas foram realizadas nas residências de minhas interlocutoras. Outras, nas de amigas(os) delas. Embora as cinco protagonistas deste artigo me tenham autorizado a citar seus verdadeiros nomes, preferi atribuir-lhes pseudônimos no intuito de preservar-lhes o anonimato.

9 "Segundo Butler, o conceito de 'matriz heterossexual' designa a base de inteligibilidade cultural através da qual se naturaliza corpos, gêneros e desejos. Essa matriz definirá o modelo discursivo/epistêmico hegemônico de inteligibilidade de gênero, o qual supõe que para o corpo ter coerência e sentido deve haver um sexo estável, expressado mediante o gênero estável (masculino expressa homem, feminino expressa mulher)" (Bento, 2006: 77n). Ver ainda Rich (1981), Wittig (2001).

10 Para uma leitura crítica de alguns dos principais trabalhos sobre sociedades camponesas no Brasil, onde é apontada a ausência da problematização acerca de conjugalidades, sexualidades e identidades de gênero “dissidentes", isto é, que escapam à heteronormatividade, ver Ferreira (2006).

11 Emprego aqui o termo "travestilidade" concordando com Pelúcio (2009, p. 78n), para quem "[o] termo travestilidade é usado (...) não só para marcar a heterogeneidade de possibilidades identitárias das travestis, como também em substituição ao sufixo 'ismo', que remete à doença e a patologias”.

12 O termo "heteronormatividade", cunhado por Michael Warner (1991), refere-se ao papel central e restritivo que a heterossexualidade assume em uma sociedade.

13 Importante destacar que, no referido contexto, a denominação "branco" contrapõe-se à de "índio", isto é, ser "branco" aqui significa não ser "índio", independentemente da cor da pele e dos traços fenotípicos do sujeito assim categorizado em termos étnico-raciais. A propósito das categorias "branco"/"particular"/"não índio" versus "índio"/"índio puro"/"índio misturado"/“caboclo", no contexto Potiguara, consultar os trabalhos de Palitot (2005: 12-14) e Vieira (2001: 68; 2003: 153).

14 "O gênero adquire vida a partir das roupas que compõem o corpo, dos gestos, dos olhares, de uma estilística definida como apropriada. São esses sinais exteriores, postos em ação, que estabilizam e dão visibilidade ao corpo, mas também são as repetições descontextualizadas do 'contexto natural' dos sexos que possibilitam a emergência de práticas que interrompem a reprodução das normas de gênero. Nas diferentes maneiras possíveis de repetição, na ruptura ou na repetição subversiva desse estilo, é que se encontrarão possibilidades para transformar o gênero" (Bento, 2006: 90-92). Ver também Bento (2004: 144-145).

15 Instituído em 2003, durante o governo do Presidente Luiz Inácio Lula da Silva, o Bolsa Família é um programa de transferência de renda que beneficia famílias em situação de "pobreza" e de "extrema pobreza". O programa integra o Fome Zero, que tem como objetivo "assegurar o direito humano à alimentação adequada, promovendo a segurança alimentar e nutricional da população mais vulnerável à fome”. A depender da renda familiar por pessoa (limitada a $\mathrm{R} \$ 140)$, do número e da idade dos filhos em idade escolar, o valor do benefício recebido por cada indivíduo varia entre $\mathrm{R} \$ 22$ e $\mathrm{R} \$ 200$. Em 2010, cerca de 1.151 famílias eram atendidas pelo programa na Baía da Traição; 1.348 em Marcação e 3.329 em Rio Tinto. Os dados não discriminam o status étnico dos sujeitos assistidos. Jennifer recebia o benefício por ser responsável pelo seu irmão pequeno, que estava em idade escolar. Para mais informações sobre o Programa Bolsa Família, acessar o site do Ministério do Desenvolvimento Social e Combate à Fome: 
www.mds.gov.br/bolsafamilia

16 Para Pacheco de Oliveira (1988: 14), indianidade consiste num "modo de ser característico de grupos indígenas assistidos pelo órgão tutor" - no caso, a Fundação Nacional do Índio (Funai) - "modo de ser" distinto "do modo de vida resultante do arbitrário cultural de cada um" (ênfases do autor). A respeito desta categoria, ver ainda Sidnei Peres (2010: 63-64n).

17 Teixeira (2008: 285) observou em sua pesquisa que "a saída das travestis para a Itália e as condições para a permanência nos primeiros tempos se estabelece por acionamento de redes informais de amizade, gênero e parentesco. Em vários trabalhos sobre migração é possível identificar o acionamento de redes sociais que possibilita a saída e a recepção nos locais de destino. Essas ações, que envolvem as informações sobre o local, o compartilhamento ou a indicação de abrigo, até mesmo o empréstimo ou a compra de passagens, são reconhecidas e nomeadas por diferentes sujeitos envolvidos na transação como 'ajuda"'.

18 Sobre a "gramática da cópula" (Heilborn, 2004: 183-186), regida pelas noções de "atividade" e "passividade" nas interações sexuais, ver, entre outros, Misse (1979), Fry (1982a, 1982b), Parker (1991), Vale de Almeida (1995), Benedetti (2005: 119), Kulick (2008).

19 Vale lembrar que Rio Tinto abriga um dos campi da Universidade Federal da Paraíba, e Mamanguape (cidade com cerca de 42.537 habitantes [IBGE, 2012]), algumas instituições particulares de ensino superior, onde diversas pessoas da Baía da Traição e Marcação estudavam. Importante registrar também que a "vida noturna" de Rio Tinto e Mamanguape era bem mais movimentada, havendo espetáculos musicais com mais frequência, mais eventos políticos e culturais, uma quantidade maior de bares, restaurantes, além de "cabarés" onde atuavam também travestis, ao contrário da Baía da Traição e de Marcação.

\section{Referências bibliográficas}

AltMan, Dennis

1996 “On Global Qeering”. Australian Humanities Review (2), julho-agosto.

APPADURAI, Arjun

1994 "Disjunção e diferença na economia cultural global”. In: FEATHERSTONE, Mike (org.). Cultura global: nacionalismo, globalização e modernidade. Petrópolis, Vozes, pp. 311-27

Arán, Márcia e PeiXoto Júnior, Carlos Augusto

2007 "Subversões do desejo: sobre gênero e subjetividade em Judith Butler". Cadernos Pagu, (28): 129-147.

ARruti, José Maurício Andion

1996 O reencantamento do mundo: trama bistórica e arranjos territoriais Pankararu. Dissertação de Mestrado, Museu Nacional/UfrJ. 
2004 “A árvore Pankararu: fluxos e metáforas da emergência étnica no sertão do São Francisco". In PACHeCo De Oliveira, João (org.). A viagem da volta: etnicidade, política e reelaboração cultural no Nordeste indígena. Rio de Janeiro, Contra Capa Livraria/Laced, pp. 231-279

\section{BenedeTti, Marcos}

2005 Toda feita: o corpo e o gênero das travestis. Rio de Janeiro, Garamond.

Bento, Berenice

2004 "Da transexualidade oficial às transexualidades". In Piscitelli, Adriana; Gregori, Maria Filomena e CARRARA, Sérgio (orgs.), Sexualidade e saberes: convenções e fronteiras. Rio de Janeiro, Garamond, pp. 143-172.

2006 A reinvenção do corpo: sexualidade e gênero na experiência transexual. Rio de Janeiro, Garamond.

BOURDIEU, Pierre 2007 A distinção: crítica social do julgamento. São Paulo/Porto Alegre, Edusp/Zouk. BRAH, Avtar

2002 Cartographies of Diaspora. Nova York, Routledge.

Brah, Avtar e Phoenix, Ann

2004 “Ain't I a Woman? Revisiting Intersectionality”. Journal of International Women's Studies, Bridgewater, v. 5, n. 3: 75-86.

BUTLER, Judith

2003 Problemas de gênero. Rio de Janeiro, Civilização Brasileira.

CANCLINI, Néstor García

1999 Consumidores e cidadãos: conflitos multiculturais da globalização. Rio de Janeiro, Editora UFRJ.

2007 Diferentes, desiguais e desconectados: mapas da interculturalidade. Rio de Janeiro, Editora UFRJ.

Cardoso de Oliveira, Roberto

2006 Caminhos da identidade: ensaios sobre etnicidade e multiculturalismo. São Paulo/Brasília, Editora Unesp/Paralelo 15.

CoHEn, Ronald

1978 "Ethnicity: Problem and Focus in Anthropology". Annual Review of Anthropology, n. 7:379-403. 
DUARTE, Luiz Fernando Dias

2004 "A sexualidade nas ciências sociais: leitura crítica das convenções". In Piscitelli, Adriana; Gregori, Maria Filomena e CARrara, Sérgio (orgs.), Sexualidade e saberes: convenções e fronteiras. Rio de Janeiro, Garamond, pp. 39-80.

DUQue, Tiago

2009 Montagens e desmontagens: vergonha, estigma e desejo na construção das travestilidades na adolescência. São Carlos, dissertação, UFSCar.

ERIBON, Didier

2008 Reflexões sobre a questão gay. Rio de Janeiro, Companhia de Freud.

ERIKSEN, Thomas H.

1991 "The Cultural Contexts of Ethnic Differences". Journal of the Royal Anthropological Institute, v. 26, n. 1.

ERIKSON, Erik

1972 [1968] Identidade, juventude e crise. Rio de Janeiro, Jorge Zahar Editores.

FACCHINI, Regina

2009 "Entrecruzando diferenças: mulheres e (homo)sexualidades na cidade de São Paulo”. In DíAz-Benítez, María Elvira e Fígari, Carlos Eduardo (orgs.). Prazeres dissidentes. Rio de Janeiro, Garamond, pp. 309-341

Ferreira, Paulo Rogers

2006 Os afectos mal-ditos: o indizivel das sexualidades camponesas. Brasília, dissertação. Universidade de Brasília.

FRIEDMAN, Jonathan

1994 "Ser no mundo: globalização e localização". In FeAtherstone, Mike (org.).

Cultura global: nacionalismo, globalização e modernidade. Petrópolis, Vozes, pp. 329-348.

FRY, Peter

1982a "Homossexualidade masculina e cultos afro-brasileiros". In Para inglês ver: identidade e politica na cultura brasileira. Rio de Janeiro, Jorge Zahar Editor, pp. $54-86$.

1982b "Da hierarquia à igualdade: a construção histórica da homossexualidade no Brasil". In _. Para inglês ver: identidade e política na cultura brasileira. Rio de Janeiro, Jorge Zahar Editor, pp. 87-115.

GARBER, Marjorie

1991 Vested Interests: Cross-Dressing and Cultural Authority. Nova York, Routledge. 
GARCIA JR., Afrânio Raul

1983 Terra de trabalho: trabalho familiar de pequenos produtores. Rio de Janeiro, Paz e Terra.

1989 O sul: caminho do roçado. Estratégias de reprodução camponesa e transformação social. São Paulo, Marco Zero; Brasília, Editora Universidade de Brasília, МСт/CNPq.

GEERTZ, Clifford

2000 Nova luz sobre a antropologia. Rio de Janeiro, Jorge Zahar Editor.

GRÜNEWALD, Rodrigo de Azeredo

1993 Regime de indio e faccionalismo: os Atikum da Serra do Umã. Rio de Janeiro, dissertação, Museu Nacional/UfrJ.

GUPTA, Akhil e FERGUSON, James

1992 "Beyond 'Culture': Space, Identity, and the Politics of Difference". Cultural Anthropology, v. 7, n. 1: 6-23.

HANNERZ, Ulf

1997 "Fluxos, fronteiras, híbridos: palavras-chave da antropologia transnacional". Mana, 3 (1): 7-39.

HeILBORN, Maria Luiza

2004 Dois é par: gênero e identidade sexual em contexto igualitário. Rio de Janeiro, Garamond.

Heredia, Beatriz Maria Alásia de

1979 A morada da vida: trabalho familiar de pequenos produtores do Nordeste do Brasil. Rio de Janeiro, Paz e Terra.

1989 Formas de dominação e espaço social: a modernização da agroindústria canavieira em Alagoas. São Paulo/Brasília, Marco Zero/MTC/CNPq.

KULICK, Don

2008 Travesti: prostituição, sexo, gênero e cultura no Brasil. Rio de Janeiro, Editora Fiocruz.

LAIDLAW, James

2002 "For an Anthropology of Ethics and Freedom". The Journal of the Royal Anthropological Institute, v. 8, n. 2.

MCCLINTOCK, Anne

2010 Couro imperial: raça, gênero e sexualidade no embate colonial. Campinas, SP, Editora da Unicamp. 
Misse, Michel

1979 O estigma do passivo sexual. Rio de Janeiro, Achiamé.

Moore, Henrietta L.

2000 "Fantasias de poder e fantasias de identidade: gênero, raça e violência". Cadernos Pagu n. 14: 13-44.

NAGEL, Joane

2003 Race, Ethnicity, and Sexuality: Intimate Intersections, Forbidden Frontiers. Nova York/Oxford: Oxford University Press.

OKAMURA, Jonathan Y.

1981 "Situational Ethnicity". Ethnic and Racial Studies, v. 4, n. 4: 452-465.

OliveIRA, Neuza Maria de

1994 Damas de paus: o jogo aberto dos travestis no espelho da mulher. Salvador, Centro Editorial e Didático da UFBA.

Pacheco de Oliveira, João

1988 “O nosso governo”: os Ticuna e o Regime Tutelar. São Paulo, Editora Marco Zero.

1999 “A problemática dos 'índios misturados' e os limites dos estudos americanistas: um encontro entre antropologia e história”. In . Ensaios em antropologia histórica. Rio de Janeiro, Editora UFRJ, 99-123.

PALITOT, Estévão Martins

2005 "Economia moral, poder tutelar e conflito: o campo Potiguara no século Xx". Trabalho final apresentado no curso Seminários Avançados em Sociologia II, Campina Grande. (texto não publicado).

PARKER, Richard

1991 Corpos, prazeres e paixões: a cultura sexual no Brasil contemporâneo. São Paulo, Best-Seller.

2002 Abaixo do equador: culturas do desejo, homossexualidade masculina e comunidade gay no Brasil. Rio de Janeiro, Record.

PASINI, Elisiane

2009 "Sexo com prostitutas: uma discussão sobre modelos de masculinos". In Díaz-Benítez, María Elvira e Fígari, Carlos Eduardo (orgs.). Prazeres dissidentes. Rio de Janeiro, Garamond, pp. 237-262. 
Patrício, Maria Cecília

2008 No truque: transnacionalidade e distinção entre travestis brasileiras. Recife, tese, Ppgas/UfPE.

Pelúcio, Larissa

2005 "Na noite nem todos os gatos são pardos: notas sobre a prostituição travesti”. Cadernos Pagu, n. 25: 217-248.

2007 Nos nervos, na carne, na pele: uma etnografia sobre prostituição travesti e o modelo preventivo de Aids. São Carlos, tese, UFSCar.

2009 "Gozos ilegítimos: tesão, erotismo e culpa na relação sexual entre clientes e travestis que se prostituem". In DíAZ-BeníteZ, María Elvira e FíGARI, Carlos Eduardo (orgs.). Praz̧eres dissidentes. Rio de Janeiro, Garamond, pp. 71-91.

Peres, Sidnei

1992 Arrendamentos de terras indígenas: análises de alguns modelos de ação indigenista no nordeste (1910-1960). Rio de Janeiro, dissertação, Museu Nacional/UfRJ.

2010 "Associativismo pluriétnico e etnicidade religiosa: tradições e modernidades em dois contextos etnográficos regionais". In REIS, Daniel Aarão et al. (orgs.), Tradicões e modernidades. Rio de Janeiro, Editora FGV., pp. 61-76.

PERES, William

2005 Subjetividade das travestis brasileiras: da vulnerabilidade da estigmatização à construção da cidadania. Rio de Janeiro, dissertação, IMS/UERJ.

Poutignat, Philippe e STREIFF-Fenart, Jocelyne

1998 Teorias da etnicidade. Seguido de grupos étnicos e suas fronteiras de Fredrik Barth. São Paulo, Fundação Editora da Unesp.

RiCH, Adrianne

1981 “La coninte à L'hétérosexualité et léxistence lesbienne”. Nowvelles questions féministes, n. 1, Paris: Tierce.

SiLVA, Hélio R. S.

2007 Travestis: entre o espelho e a rua. Rio de Janeiro, Rocco.

SIQUEIRA, Deis

2006 "Prefácio". In: BENTO, Berenice. A reinvenção do corpo: sexualidade e gênero na experiência transexual. Rio de Janeiro, Garamond, pp. 11-18. 


\section{STOLCKE, Verena}

1993 "Is Sex to Gender as Race is to Ethnicity?" In VALLE, Teresa del (org.), Gendered Anthropology. Londres, Routledge, pp. 17-37.

TeIXeIra, Flávia do Bonsucesso

2008 “L'Italia dei Divieti: entre o sonho de ser européia e o babado da prostituição". Cadernos Pagu, n. 31: 275-308.

TOTA, Martinho

2012 Entre as diferenças: gênero, geração e sexualidades em contexto interétnico. Rio de Janeiro, tese, Museu Nacional/UfRJ.

Vale de Almeida, Miguel

1995 Senhores de si: uma interpretação antropológica da masculinidade. Lisboa, Fim de século. VALLE, Carlos Guilherme Octavianno do

1993 Terra, tradição e etnicidade: um estudo dos Tremembé do Ceará. Rio de Janeiro, dissertação, Museu Nacional/UfrJ.

Vieira, José Glebson

2001 A(Im)pureza do sangue e o perigo da mistura: uma etnografia do grupo indígena Potyguara da Paraíba. Curitiba, dissertação, UFPR.

2003 “De 'noiteiro’ a cacique: constituição da chefia indígena Potiguara da Paraíba”. Revista Anthropológicas, ano 7, v. 14 (1/2): 145-160.

WARNER, Michael

1991 "Introduction: Fear of a Queer Planet". Social Text, 9 (4 [29]): 3-17.

WiTTIG, Monique

2001 La pensée straight. Paris, Éditions Balland.

Young, Robert J. C.

2005 Desejo colonial: hibridismo em teoria, cultura e raça. São Paulo, Perspectiva. 


\section{Five Lives: transvestilidades, gender, sexualities, and ethnicities in Paraíba/Brazil}

ABSTRACT: The most important social and anthropological studies about lesbians, gays, transvestites and transsexuals produced in Brazil was made in urban or metropolitan context, so that we unknow about how people experience sexualities and gender identities that diverge from the "heterosexual matrix" in other areas, such as rural areas, small towns or indigenous territories. Moreover, in the specific case of the works on transvestites, we observed an mecanic and appellant association between "travestilidade" and prostitution. Thus, this article aims - from the life stories of five indigenous transvestites, inhabitants of cities in the state of Paraiba - provide a contribution to aggregate other components to researchers investiganting transvestites as well as blend the problem of prostitution through speeches and biographical peculiarities of my five interlocutors.

KEYWORDS: “Travestilidade”, Sexuality, Gender, Ethnicity, Life Stories.

Recebido em janeiro de 2012. Aceito em janeiro de 2015. 